\title{
近接場光学顕微鏡による半導体量子構造のイメージング分光
}

\author{
斎木 敏治 \\ 慶應義熟大学 理工学部電子工学科 ( $2223-8522$ 神奈川県横浜市港北区日吉3-14-1)
}

\section{Near-Field Optical Imaging Spectroscopy of Semiconductor Quantum Structures}

\author{
Toshiharu SAIKI \\ Department of Electronics and Electrical Engineering, Keio University, \\ 3-14-1 Hiyoshi, Kohoku-ku, Yokohama, Kanagawa 223-8522
}

(Received November 17, 2005)

\begin{abstract}
We describe photoluminescence imaging spectroscopy based on a near-field scanning optical microscope (NSOM). By refining the design and fabrication method of a NSOM probe, the spatial resolution has been remarkably improved as high as $30 \mathrm{~nm}$. The resolution allows us to map out the wavefunction of an exciton confined in a large quantum dot. In this article we study a variety of quantum confinement structures: interface fluctuation GaAs quantum dots (QDs) with a typical size of $100 \mathrm{~nm}$, electrostatic field induced GaAs QDs of $500 \mathrm{~nm}$, and nitrogen clustering induced quantum confinement structures in GaNAs ranging from smaller than $30 \mathrm{~nm}$ (the spatial resolution) to several hundreds $\mathrm{nm}$. In the case of the interface QDs, the quantum energy spacing exceeds the thermal energy and therefore the wavefunctions of individual exciton states are successfully visualized. In the other cases, since the interlevel energy spacings are rather small, we discuss our results in terms of local densities of states.
\end{abstract}

Key Words: Near-field scanning optical microscope (NSOM), Photoluminescence, Wavefunction, Quantum dot, Exciton

1.はじめに

半導体量子ナノ構造を個別に解析する, あるいは半導 体結晶の不均一性を仔細に観察する上で適切な空間分解 能を有する分光手法が必須である1). 高開口数レンズを用 いた顕微分光の場合，ほほ波長程度の分解能が得られ る. 低温測定でもセットアップは簡便であり, 分解能に 不満がなければ手軽に実験ができる。しかし, 密集した 量子構造を観察したり, 短距離スケールでの結晶不均一 性を解明したりする際には, より高い分解能が必要とな る. 1980年代より研究が始まった近接場光学顕微鏡 (Nearfield Scanning Optical Microscope; NSOM) は着実に性能を 伸ばし，高空間分解能に対するこれらの需要に応えてい る. 特に最近の分解能向上は著しく, 10 30 nmの分解能 で分光計測が可能となるに至っている.

分解能向上にともない，量子構造の内部を嗄き込む， すなわち電子の波の広がりを直接可視化することができ るようになってきた. 量子力学ではじめに勉強する井戸 型ポテンシャルの波動関数が光で見えるようになること は, 純粋に興味が引かれるが, 半導体材料評価の上でそ の意義は大きい. 例えば半導体混晶のポテンシャルゆら ぎは自然形成的な量子ドットとみなすことができるが,
その空間的な大きさ・形状の推定のためには電子のひろ がりを直接マッピングすることが必要である。精密なエ ネルギー分光, 偏光分光や時間分解分光と組み合わせる ことにより, 得られる情報は計り知れない.また，ひと つながりの電子の波の一部を光で照射するということ は, 光と電子の相互作用についての長波長近似 (波長に比 べて電子のひろがりはずっと狭いと近似する)が適用でき ない状況を生み出す。その結果, 遷移選択則の破綻に よって本来は到達できないはずの量子状態へアクセスが 可能となる．新しい量子デバイスや光化学プロセスの創 成に向けて大きなヒントとなる。

本稿では, $30 \mathrm{~nm}$ の空間分解能を有する近接場分光イ メージング技術を駆使し，GaAs量子ドット(アイランド) に閉じ込められた励起子の波動関数マッピング，GaNAs 混晶におけるキャリアの局在 ·非局在状態の解明, 静電 閉じ込め量子ドットの局所状態密度イメージングに取り 組んだ結果をご紹介したい。

\section{2. 近接場イメージング分光法}

本研究ではいわゆる開口型NSOMを使用している. Fig. にに示すように，先鋭化した光ファイバに遮光用金属膜 

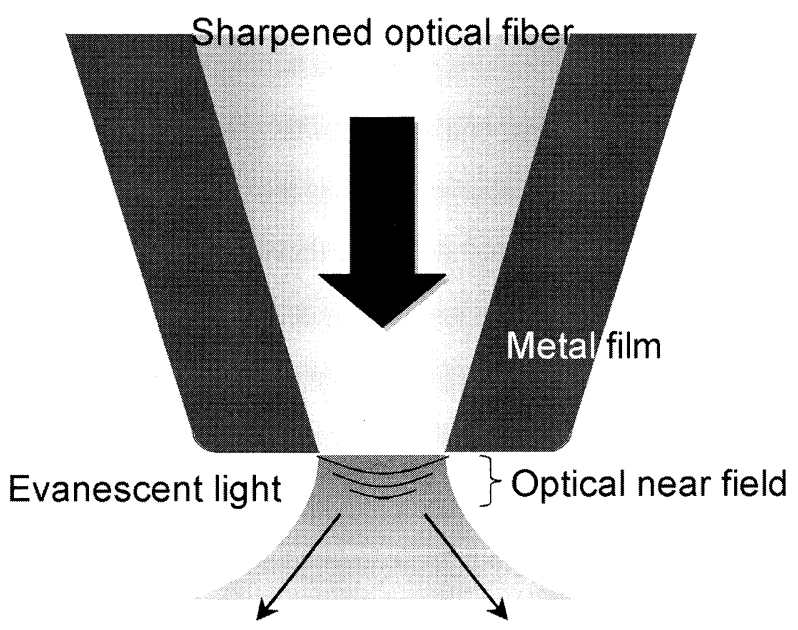

Propagating light

Fig. 1 Schematic of an aperture probe tip and the light field emanating from the aperture.

(アルミニウムや金)を施し，先端に波長よりもずっと小さ な開口を設けたものをプローブとして使用する。ファイ バに導入され，先端まで到達したレーザー光は開口から 染み出し，エバネッセント光として振る舞う。なお，一 部の光は伝搬光として開口から漏れ出す。これらエバ ネッセント光と伝搬光が一体となって, 開口直下には近 接場光と呼ばれる開口サイズ程度の光スポットを形成す る.

プローブの作製にあたってはフッ酸による光ファイバ の化学エッチング法を利用し2), 金属遮光膜として金を テーパー構造全体にスパッタリングコートする．最後に プローブ先端を試料自身あるいはサファイア基板などに 押し付けることにより開口を作製する3)。開口径は小さい 場合で $30 \mathrm{~nm}$ 以下のものを作製可能である。単一蛍光分子 イメージングや単一量子ドットイメージングを通して, 実際に30 nmの空間分解能が確認されている4,5).

実際のNSOM測定に扔ける光の照射方法や信号の集光方 法は，プローブ，試料の形態や信号の種類によってさま ざまである。これは他の走査型プローブ顕微鏡と比較し て際だった特徴であり，NSOMが多様な試料に対応可能で あることの現れでもある．Fig. 2に装置構成の一例を示 す。ここでは，開口を通してレーザー光を試料に照射 し，試料からのフォトルミネッセンス $(\mathrm{PL})$ をふたたび開 口によって集光する．PL信号は分光器に導かれ，CCD力 メラによってそのスペクトルを計測する。スキャナを 使って試料を二次元的に走査し，プローブの位置の関数 としてスペクトルデータを蓄積する，すべてのデータを 取得後, 発光エネルギーごとに発光分布を二次元画像化 する，高分解能を得るためには，プローブ先端と試料表 面との距離は開口半径以下，多くの場合 $10 \mathrm{~nm}$ 以下に保つ 必要がある。距離制御の方法としては，プローブ先端と 試料表面との間に働く力学的な相互作用を水晶振動子で 検知し，フィードバック信号として利用する場合が多 い。な掞本稿で紹介する測定はすべてへリウム温度の低 温環境で㧍こなっている。

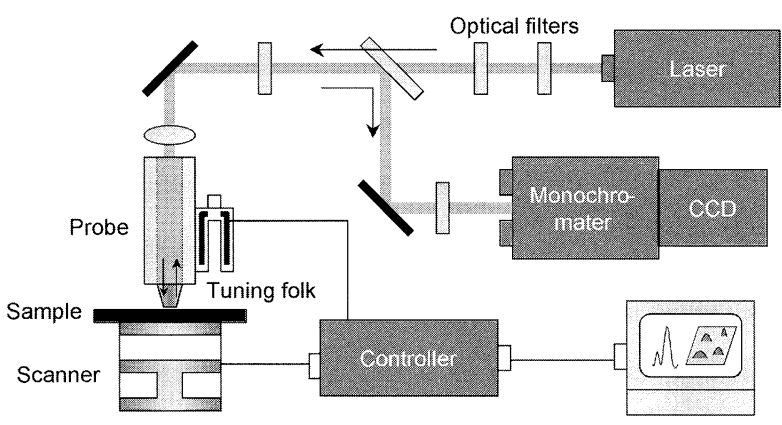

Fig. 2 Experimental setup for near-field optical imaging spectroscopy.

\section{GaAs量子アイランドに閉じ込められた 励起子の波動関数マッピング}

ここでは，GaAs量子井戸内で自然形成的に作られる比 較的大きな量子ドット(アイランド)を観察対象とし，そこ に閉じ込められた励起子，励起子分子，ならびにその励 起状態の波動関数をマッピングした結果を紹介する6)。観 察対象は，分子線エピタキシー(MBE)にて作製したAlAs/ GaAs/AlGaAs量子井戸を基本構造とする．Fig. 3に示すよ うに，量子井戸の界面には1２原子層分の厚さゆらぎが 存在する。ここで，1層分だけ井戸層が厚い領域(このよ うに厚さの一様な広い領域をアイランドと呼ぶ)に着目す ると，そこでは量子閉じ込めが若干弱く，周囲よりも工 ネルギー的に安定になる。つまり，アイランド部分は厚 さ方向だけでなく，面内方向にも緩い閉じ込め構造とな り，擬似的な量子ドットとみなすことができる。しかも MBE技術の向上により，このアイランドを大きく成長さ せることが可能となり，100 nm程度のサイズが実現して いる。このような大きなアイランドは，そのサイズに比 例して光との相互作用も増強する(励起子が並進運動でき る領域が広がり，光学遷移のモーメントが増大寸る)た め，デバイスへの応用上も非常に重要な系である。

本測定では，厚さ $5 \mathrm{~nm}$ のaAs量子井戸中に形成された 大きさ $100 \mathrm{~nm}$ 前後のアイランド構造を対象として, 低温 動作NSOMによって発光イメージング分光を抢こなった。 測定温度は8１0 Kである。開口径20〜30 nmのプローブ を使用し，空間分解能は $30 \mathrm{~nm}$ であることを確認してい る5). 光学特性の確保を目的として量子井戸が保護層(こ こでは厚さ $20 \mathrm{~nm}$ )で覆われているため, 分解能としてはこ の值がほぼ限界である。半導体レーザーを励起光源と し，量子井戸内に励起子を生成する，励起子は井戸内を 拡散した後, 最終的にアイランドに緩和し, 再結合す る.このPL発光をプローブで集光し，分光をおこなう.

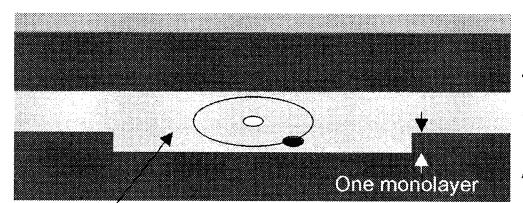

GaAs cap layer AIGaAs barrier layer GaAs quantum well AlAs barrier layer

Quantum dot (island)

Fig. 3 Schematic of an interface fluctuation quantum dot. 
10〜30 nmのステップで2次元的にプローブを走査し, 各 点でPLスペクトルを測定する。拈よそ1000枚のPLスペク トルを蓄積した後, 発光ピークごとにその空間分布を画 像化する。

Fig. 4はある1つのアイランドからのPL発光を, 励起光 強度を变化させながら測定したNSOM発光スペクトルであ る。弱励起領域では単一のPLピークが見られるが，励起 強度の増大にともない，2つ目のピークが低エネルギー側 に出現する。励起強度に対するピーク強度の変化, およ び2つのピークのエネルギー差より，それぞれがアイラン ドに閉じ迄められた励起子 $(\mathrm{X}, \mathrm{E}=1.6088 \mathrm{eV})$, 励起子分 子 $(\mathrm{XX}, \mathrm{E}=1.6057 \mathrm{eV})$ からの発光であることを確認して いる。励起子分子とは，2つの励起子による束縛状態であ り (水素原子と水素分子の関係に類似), XとXXのピーク のエネルギー差はその束縛エネルギーに対応する。励起 子分子はアイランド内に同時に2つの励起子が存在すると きに形成され，その確率は励起強度に対して2乗で増大す る.

続いて，さまざまな量子アイランドにおいてX，XXの それぞれのピーク信号に対して2次元的な空間発光分布を 画像化した結果がFig. 5である。本実験の空間分解能(30 $\mathrm{nm})$ よりもイメージサイズが大きいこと，イメージの形状 が特定の結晶軸方向を向いた楕円形になっている(この事 実はSTMによってすでに報告されている)ことから，アイ ランド形状を反映したPL発光プロファイルを観察してい ることがわかる。またいずれのドットにおいても，明ら かにXXの方がXよりもイメージサイズが小さい。この結 果を定量的に解釈するため, 理想的な円形のGaAs量子 ディスクを仮定し, 励起子状態 $(\mathrm{X})$ と基底状態間, ならび に励起子分子状態 $(\mathrm{XX})$ と励起子状態 $(\mathrm{X})$ 間の遷移につい ての分極場を計算した。基本的に前者は閉じ迄めを受け

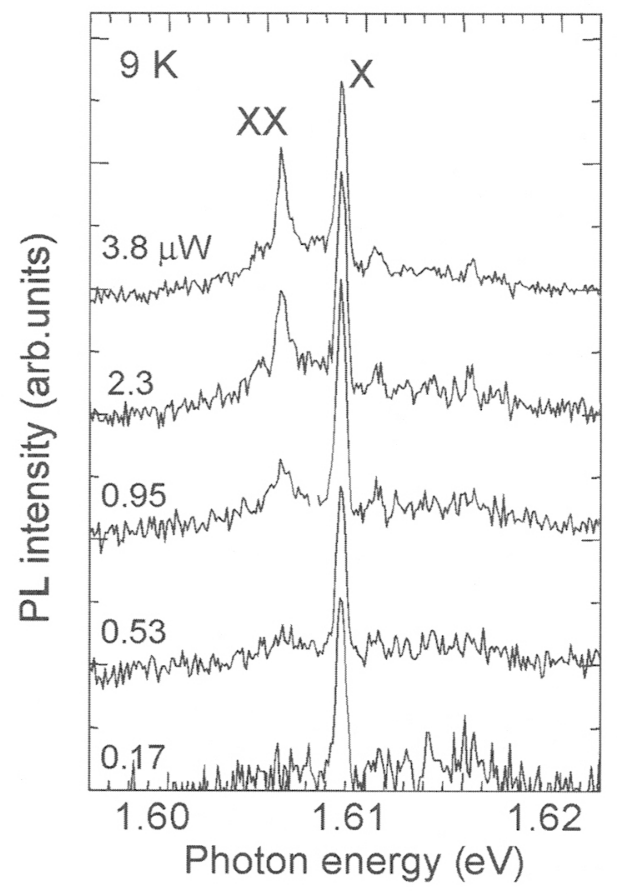

Fig. 4 Evolution of photoluminescence spectra from single quantum dot with excitation density.
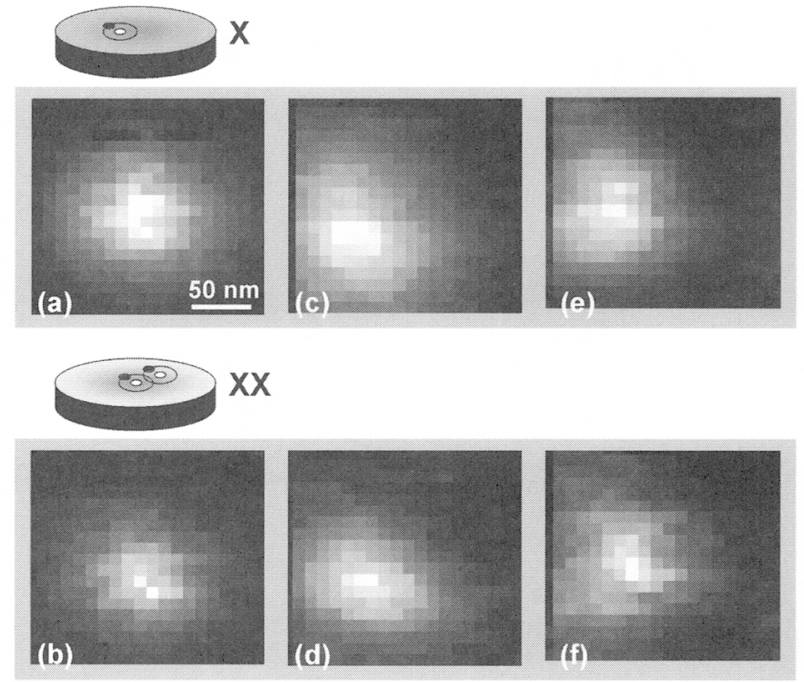

Fig. 5 Two-dimensional mapping of PL intensity of excitons and biexcitons confined in a quantum dot. (a) and (b), (c) and (d), (e) and (f) are obtained from the same quantum dots, respectively.

た励起子の包絡関数, 一方後者は励起子分子と励起子の それぞれの包絡関数の重なり積分を反映することにな る。ここでは計算結果は省略するが, 実験結果と定量的 に良い一致を示していることが確認された6). 以上の結果 を総合して, 今回われわれは, 量子アイランドに閉じ込 めら扎た励起子重心運動の波動関数の可視化に成功した と結論付けた。

Fig. 6(a)，（b)はそれぞれ，あるアイランドの励起子と その励起状態に関する同様のイメージングの結果であ る7)。ここで観測されているアイランドは，上で示したよ
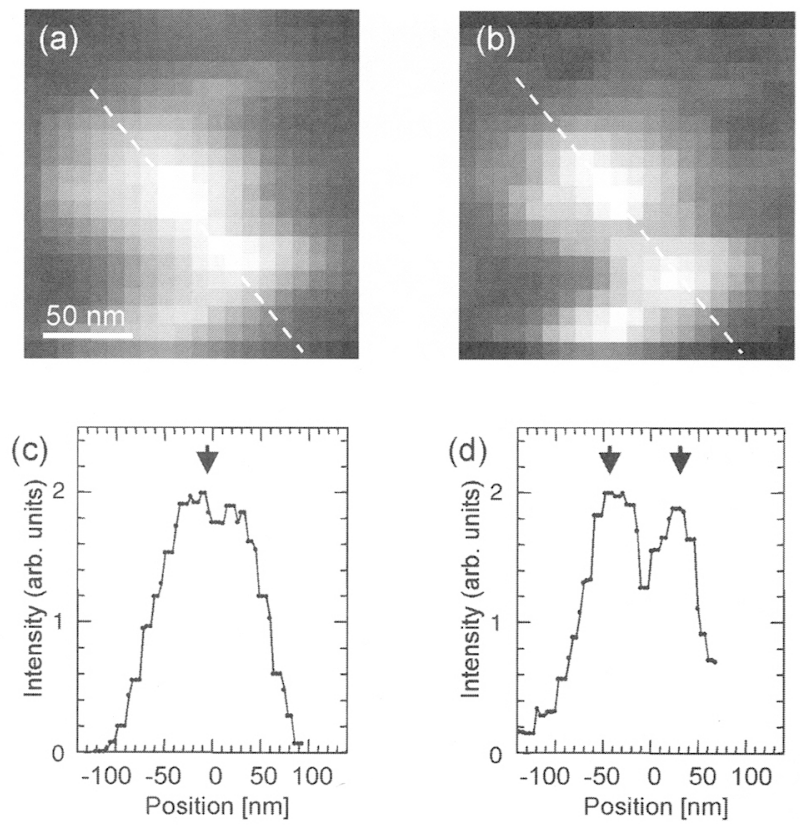

Fig. 6 Two-dimensional mapping of PL intensity from (a) the exciton ground state and (b) the first-excited state. (c), (d) Cross-sectional profiles of emission intensity plotted along the dashed lines in (a) and (b), respectively. 
うな単純な楕円形状をしているものではなく, 複雑な形 をしていることが画像からわかる，注目すべきは，Fig. 6 (c)に示すように, 基底状態の発光断面プロファイルは1つ のピークしかもたない単純な構造であるのに対し, Fig. 6 (d)の励起状態のプロファイルには，はっきりと2つのピー クが観測されていることである。つまり，アイランドに 閉じ込められた励起子の励起状態が節を持った波動関数 であることを，発光イメージングを通して観測すること ができている。

\section{GaNAsにおける励起子の局在・ 非局在状態の解明}

光デバイスの基本材料であるIII-V族半導体のGaAsに対 してわずかに窒素Nを添加(<1\%)すると，そのバンド ギャップは添加量に応じて急激に減少する(巨大バンド ギャップボウイング)ことがよく知られている。具体的に は，N組成の $0.5 \% の$ 変化に対して，バンドギャップは100 $\mathrm{meV}$ 変化することがわかっている。この特性により，

GaAsN，GaInAsNなどは光通信带で利用可能なデバイス材 料として非常に大きな期待を担っている。ここで，光デ バイスへの応用上最も重要な点は，バンドギャップ近傍 における光学特性であり，それは母体のGaAsに対して窒 素原子がどのような形態で混入しているか(クラスター 化・混晶化)，そしてその結果として電子(励起子) 状態が どのように広がっているかによって大きく左右される。 しかも，クラスター状態と混晶状態のいずれが支配的と なるかは，導入したNの濃度に依存する。しかしながら現 在までのところ, 窒素原子の状態(とそれに起因する電子 の局在 · 非局在状態) と光学特性との直接的な関倸は明確 にされておらず，結晶成長への決定的な情報のフィード バックはなされていない。ここでは, 高空間分解能によ る発光スペクトル測定と発光分布イメージング測定の双 方から押さえ込むことにより，窒素原子の存在形態に関 して重要な結論を得た ${ }^{8)}$.

観察対象はMOCVD法によって成長したGaAsN/GaAs (N 濃度 $0.85 \%$ ) 量子井戸である。空間分解能はやはり $30 \mathrm{~nm}$ 程度であり，測定はへリウム温度でおこなった．Fig.7 (a) のようにマクロ領域にて測定したPLスペクトルが非常に 大きな不均一広がりを示すのに対し，Fig. 7 (b)，（c）に示 すNSOMによる局所的なPLスペクトルは微細なピーク構 造をもつ，注意深く見ると，これらのピークはその幅が4 $\mathrm{meV}$ 程度の幅をもつ比較的広いスペクトル (Fig. 7 (b)) と $0.2 \mathrm{meV}$ 以下の鋭いスペクトル (Fig. 7 (c) ) に分類されるこ とがわかる。

上記の2種類の夕イプのピークについてそれぞれ空間発 光分布をマッピングした結果がFig. 8 (a)，（b)である(2つ のイメージは同一の観察領域). 鋭いピークは20３0 nmの 狭い領域からの発光であり，幅の広いピークは100 nm程 度あるいはそれ以上の領域からの発光であることが明ら かとなった。これらの結果より，量子井戸に打いて窒素 原子がクラスター化した領域と混晶化した領域が混在 し，前者では量子ドット的に励起子を強く閉じ込め，準

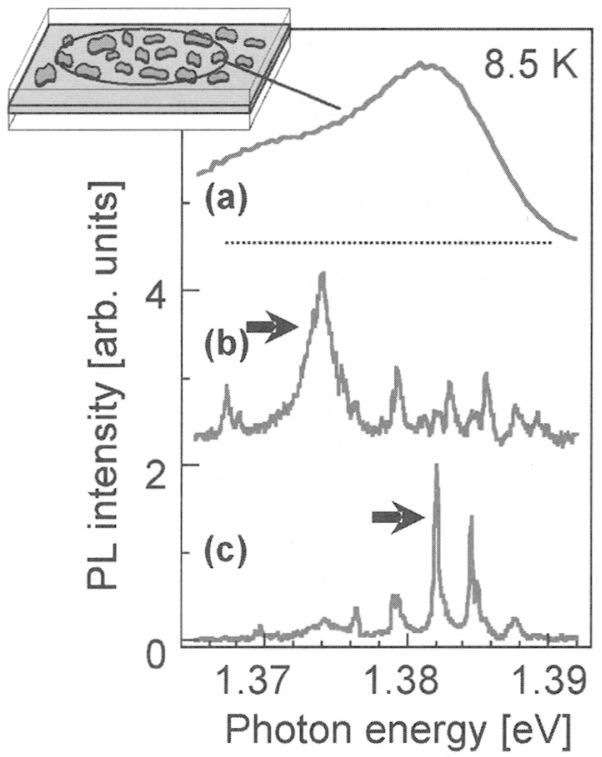

Fig. 7 (a) Far-field and (b), (c) near-field PL spectra of a single GaNAs quantum well.

(a)

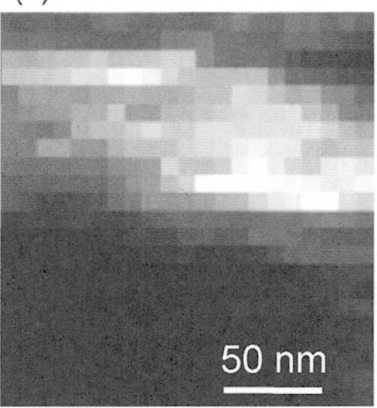

(b)

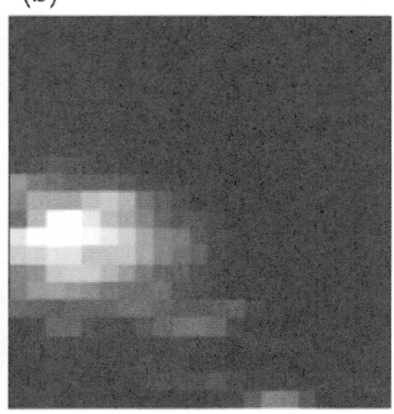

Fig. 8 (a), (b) Two-dimensional mapping of PL intensity with respect to the emission lines indicated by the arrows in Fig. 7 (b) and (c). (a) and (b) are obtained in the same scanning area.

位の離散化と発光の狭窄化を引き起こしているのに対し て，後者では励起子が弱く局在し，そのゆらぎに応じな 幅の広い発光が観測されたと推定できる.

\section{5. 静電閉じ込め量子ドットにおける 局所状態密度の観測}

半導体へテロ構造や量子井戸などの2次元のポテンシャ ルに閉じ込められた電子ガスは2次元電子ガス (2 Dimensional Electron Gas; 2DEG) と呼ばれ，主に電子デバイスへ の応用を視野に入れた研究が盛んになされている。 $2 \mathrm{DEG}$ を形成した試料表面にメッシュ状の電極を配置し，ゲー トバイアスを印加すると，横方向にも静電的に電子を閉 じ込めることができ，0次元系(量子ドット)を実現する。 ゲートバイアス電圧の調節により，閉じ込めの強さを自 由に制御できるという点が最大の特徵である。ここで は, NSOM発光分光を通して，バイアス印加によって電子 密度が空間的に変調され，横方向に閉じ込めポテンシャ ルが形成されていることを確認した9). 


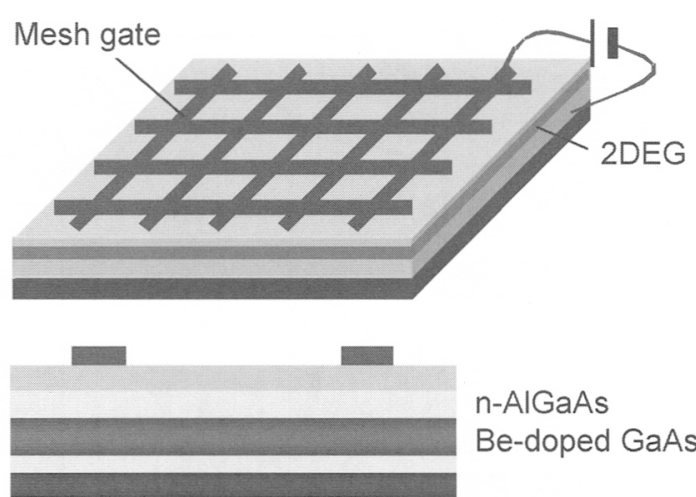

Fig. 9 Schematic of an electrostatic field induced GaAs quantum dot.

本研究で使用した試料の構造をFig. 9に示す。試料は, 分子線エピタキシー法によって作製されたBe $\delta$-ドープの $\mathrm{GaAs} / \mathrm{AlGaAs}$ 単一へテロ構造である。へテロ界面は, 表面 から $7.5 \mathrm{~nm}$ の $\mathrm{GaAs}$ キャップ層, $30 \mathrm{~nm}$ 型 $\mathrm{AlGaAs}$ 層, 40 $\mathrm{nm}$ のノンドープAlGaAs層の下に形成されている。へテロ 界面の $25 \mathrm{~nm}$ 下にはBeが $\delta$-ドープされており, これは正孔 を局在化させることにより電子の密度分布を直接観測す ることを目的としている(実空間上で強く局在したホール は波数空間では広く分布するため，さまざまな波数をも つ電子と光学的に遷移可能であり, 発光スペクトルが電 子系の状態密度を反映することがわかっている). 試料表 面には, メッシュ状に周期 $500 \mathrm{~nm}$, 幅約 $100 \mathrm{~nm}$ の Ti/Au ショットキーゲート構造が設けられている。外部からの バイアス電圧 $\left(V_{B}\right)$ は, 背面電極とメッシュの間に印加さ れている。開口径100-150 nmのプローブを用い，9Kの低 温で測定をおこなった。

Fig. 10 (a)に原子間力顕微鏡を用いて測定された試料の 表面形状像を示す。一辺が500 nmの表面ゲート構造が確 (a)

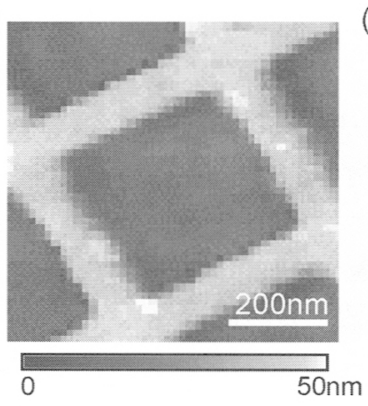

(c)

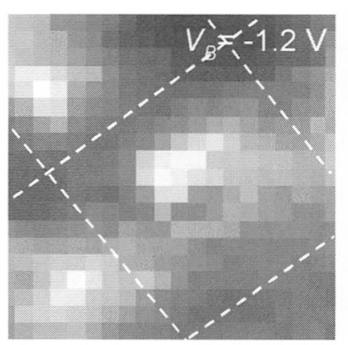

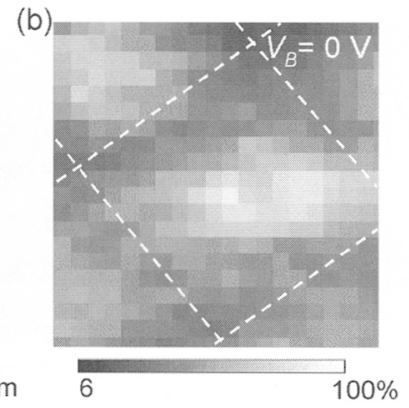

(d)

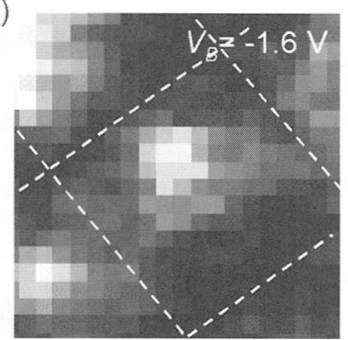

Fig. 10 Topographic image of a mash gate. (b)-(d) Twodimensional mapping of PL intensity for various bias voltages. (a)-(d) are obtained in the same scanning area.
認できる。これに対してバイアス電圧を変化させながら 測定した発光イメージをFig. 10 (b)- (d)に示す（点線は表面 ゲートの位置を表している)。この一連の発光イメージ で，バイアス電圧の印加に応じて，2次元的な発光イメ一 ジから0次元的な発光イメージへと変化してゆく様子が確 かに捉えられている。十分負バイアスを印加 $\left(\mathrm{V}_{\mathrm{B}}=-1.6 \mathrm{~V}\right)$ した時には，正方形のゲートの中心にドット状の発光イ メージが観測されている。これは，バイアス電圧の印加 によりゲート周辺の電子密度が下がり，ゲートから空間 的に離机た場所にのみ電子密度が分布している様子を示 している。

次に, 十分負のバイアス電圧が印加された 0 次元状態 で，異なる発光エネルギーで検出された発光イメージを Fig. 11 (a)- (c)に示す。低エネルギー (a) から高エネルギー 側 (c)に向かって，発光の空間分布が広がっていく様子が わかる。ここで, 発光イメージの断面強度プロファイル からその広がりを半值全幅で定義し, 発光エネルギーの 関数としてプロットしたものをFig. 11 (d)に示す。なお, 同じ図に低バイアスでのデータもプロットしてある。こ こから判ることは, 低バイアスの状態では電子系が2次元 的であることから期待されるように，発光の空間分布に はエネルギー依存性が全くなく, バイアス電圧印加で電 子系が0次元的になるに従い，その広がりがエネルギーに 強く依存するようになることである。これは，静電的な 電子の閉じ迟めが調和振動子ポテンシャルとしてよく記 述され，ポテンシャルの底の低エネルギーの電子ほど空 間的に狭い空間領域に閉じ込められていることを実験的 に観測できたことを意味する。 (a)

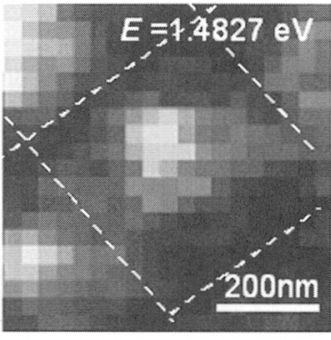

(c)

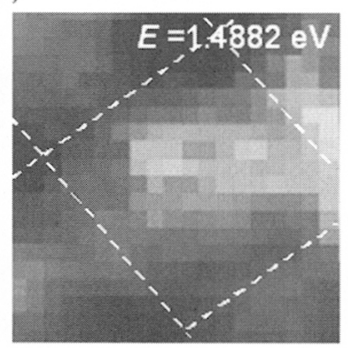

(b)

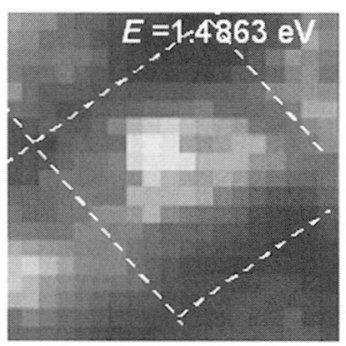

(d)

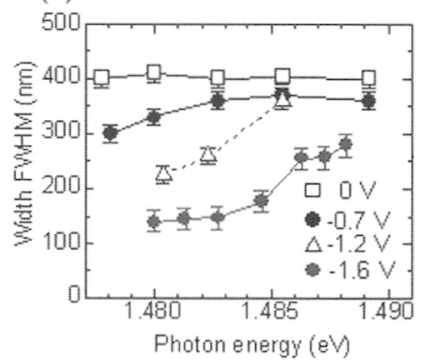

Fig. 11 (a)-(c) Two-dimensional mapping of PL intensity with a bias voltage of $-1.6 \mathrm{~V}$ for various detection photon energies. (d) Plots of PL distribution as a function of detection photon energy for various bias voltages. 


\section{6. おわりに}

以上のように，実空間におけるナノ分解能イメージン グ分光技術は, 従来のスペクトル領域の測定によって得 られた物理的解釈を確証する，あるいは時にそれを覆す ほどの有用性と説得力をもつ.もっと言えば，イメージ ングを通してはじめて物理描像が得られる場合もある。 「じっくりと観察する」ことはあらゆる科学の原点である。 近接場光学顕微鏡という道具の開発が一段落したことは 決してこの分野の研究のネタが尽きたということではな く，やっと入り口に迻り着いたと考えるべきである。ナ ノスケールにおける光と物質の相互作用の本質が見えて くるのもこれからである. 今後の研究の展開に期待した w.

\section{謝 辞}

ここで紹介した研究成果は多くの方々のご協力によっ て得られたものである.NSOMプローブの開発にあたって は, 東京大学 - 大津 元一教授, 神奈川科学技術アカデ ミー $(\mathrm{KAST}) \cdot$ 物部秀二氏による成果をもとに開発を進め た. 実験にあたっては, KAST (現京都大学) ・松田一成氏
を中心に，KAST ・ 穂坂 紀子氏，酒井 優氏にご尽力いた だいた。また, 筑波大学・野村晋太郎助教授, 理化学研 究所 - 三原勝氏, 東京工業大学 - 青柳 克信教授, 住友電 工・石塚貴司氏，高岸成典氏には試料についてサポート いただき，京都工芸繊繊大学・高河原俊秀教授には理論 計算をお願いした。これらの方々に改めてお礼申し上げ たい.

\section{参考文献}

1) 斎木 敏治, 戸田 泰則：「ナノスケールの光物性」オーム社 (2004).

2) T. Saiki, S. Mononobe, M. Ohtsu, N. Saito, and J. Kusano: Appl. Phys. Lett. 68 (1996) 2612.

3) T. Saiki and K. Matsuda: Appl. Phys. Lett. 74 (1999) 2773.

4) N. Hosaka and T. Saiki: J. Microscopy 202 (2001) 362.

5) K. Matsuda, T. Saiki, S. Nomura, M. Mihara, and Y. Aoyagi: Appl. Phys. Lett. 81 (2002) 2291.

6) K. Matsuda, T. Saiki, S. Nomura, M. Mihara, Y. Aoyagi, S. Nair, and T. Takagahar: Phys. Rev. Lett. 91 (2003) 177401.

7) T. Saiki, K. Matsuda, S. Nomura, M. Mihara, Y. Aoyagi, S. Nair, and T. Takagahara: J. Electron Microscopy 53 (2004) 193.

8) K. Matsuda, T. Saiki, T. Yamada, and T. Ishizuka: Appl. Phys. Lett. 85 (2004) 3077.

9) K. Matsuda, T. Saiki, S. Nomura, and Y. Aoyagi: Appl. Phys. Lett. 87 (2005) 43112.

\section{半導体量子ドット (quantum dot)}

電子をナノスケールの半導体の箱に閉じ込めると, 電 子がもつ波としての性質が干渉という現象を通して顕著 にあらわれる、箱の壁で反射を繰り返す波が干渉し, 定 在波のみが生き残る結果, 電子のエネルギーは(原子のよ うに)飛び飛びの值しかとることができなくなる．多くの 場合，バンドギャップのより大きな半導体で包むことに よってエネルギーの障壁を作り, 電子を閉じ込める。材 料や大きさ，形を適切に選択，制御することにより，工 ネルギー準位構造を自由に設計できることから，人工的
な原子とも呼ばれる。量子閉じ込めの結果，電子の状態 密度はバルクの場合と大きく異なったものとなり, 応用 上有利な性質がもたらされる。理想的にはすべての電子 のエネルギーを同一に揃えることができるので, 半導体 レーザーの利得媒質として利用した場合, 発振しきい值 を大幅に低減することができる。，その他，量子暗号用光 源, 量子コンピュータの構成素子などへの利用方法が考 案されている。

(斎木 敏治)

\section{表面増強ラマン散乱}

\section{(SERS: surface enhanced Raman scattering)}

原子レベルから数 $10 \mathrm{~nm}$ の粗さを有する金属表面に吸着 した化学種のラマン散乱が表面形状に依存して $10^{5}-10^{6}$ 程 度増強する現象. 約 30 年間に発見されたもので, きわめ て微弱なラマン散乱信号の高感度化に利用されている. 増強メカニズムとしては，金属ナノ構造に局在する表面 プラズモンの光励起により形成される表面電場や，特異
的な吸着サイトでの化学的増強効果が寄与していること が明らかになっている。近年，走査プローブ顕微鏡や高 感度光検出器の発達により，最適構造を有する金属ナノ 粒子のみを扱うことにより増強度を $10^{10}$ 以上に上げ，単一 分子からのラマン散乱測定も可能になってきた。

(二又政之) 